\title{
Private sector shrinkage and the growth of industrialized economies
}

\author{
MICHAEL L. MARLOW*
}

U.S. Department of Treasury, Washington, D.C. 20220

\section{Introduction}

Industrialized nations have experienced growing public sectors over this century. Measured as a share of total product, growing absorptions of resources by governments have altered the private-public sector mixes of industrialized economies. As displayed in Table 1, the average level of the public sector's share of gross domestic product (GDP) has risen from .32 to .40 over 1960 to 1980 , respectively. Much of public sector growth stems from a rapid acceleration in public outlays on social expenditure: The average ratio of social expenditure to GDP has risen from .14 to .24 over the same period.

This paper examines the hypothesis that growing public sectors retard macroeconomic growth. Even though much has been hypothesized and asserted about the effect of growing public sectors on economic growth, there exist little empirical evidence supporting the hypotheses and assertations. From a sample of 19 industrialized countries, it is found that economic growth is inversely related to public sector size over the period 1960-1980. The results of this paper suggest that shrinking private sectors not only pose threats to future over-all economic growth but constrains the future ability of public sectors to consume private resources at accelerating rates.

\section{Hypothesized relation between government and economic growth}

The notion that competitive economies efficiently allocate resources is the basis for the argument that growth in the government's share of the econ-

* I would like to thank Robert N. Mottice and William Orzechowski for their helpful comments. The views expressed here are solely those of the author and do not necessarily reflect the views of the U.S. Department of Treasury. 
Table 1. Shares of government expenditure in GDP

\begin{tabular}{|c|c|c|c|c|c|c|}
\hline \multirow[b]{2}{*}{ Country } & \multicolumn{3}{|c|}{ Total expenditure ${ }^{a}$} & \multicolumn{3}{|c|}{ Social expenditure ${ }^{\mathrm{b}}$} \\
\hline & 1960 & 1970 & 1980 & 1960 & 1970 & 1980 \\
\hline Canada & .33 & .36 & .38 & .12 & .19 & .22 \\
\hline France & .38 & .39 & .43 & $-{ }^{*}$ & - & .28 \\
\hline F.R. Germany & .33 & .37 & .42 & .20 & .23 & .29 \\
\hline Japan & .23 & .19 & .23 & .10 & .09 & .13 \\
\hline Italy & .35 & .33 & .38 & .18 & .21 & .25 \\
\hline U.K. & .36 & .38 & .42 & .14 & .18 & .22 \\
\hline U.S. & .31 & .33 & .34 & .11 & .16 & .20 \\
\hline Australia & .25 & .26 & .28 & .11 & .11 & .18 \\
\hline Austria & - & .38 & .42 & .19 & .22 & .26 \\
\hline Belgium & .31 & .37 & .48 & .17 & .25 & .36 \\
\hline Denmark & - & .41 & - & - & .26 & - \\
\hline Finland & .29 & .31 & .37 & .16 & .20 & .25 \\
\hline Greece & .27 & .28 & .31 & .09 & .11 & .13 \\
\hline Iceland & .37 & .38 & .43 & .12 & .17 & .23 \\
\hline Netherlands & .36 & .41 & .51 & .17 & .29 & .33 \\
\hline New Zealand & .35 & .27 & .34 & .14 & .13 & .18 \\
\hline Norway & .28 & .41 & .47 & .12 & .22 & .27 \\
\hline Sweden & .35 & .43 & .57 & .16 & .23 & .33 \\
\hline Switzerland & - & .21 & - & .08 & .13 & - \\
\hline Average & .32 & .34 & .40 & .14 & .19 & .24 \\
\hline
\end{tabular}

*Not available.

${ }^{a}$ Defined as current and capital outlays of central, state/provincial, local governments and social security funds.

${ }^{b}$ Defined as any direct public expenditures on education, health services, pensions, unemployment compensation, other income-maintenance programs and welfare services.

Source: OECD (1985).

omy hinders over-all economic growth. There exist many examples of where government decision-making may be viewed as inferior to the discipline of the marketplace and, therefore, detrimental to productivity and performance. Public enterprises are often viewed as less efficient or purposeful than privately-owned firms. It is argued that income-support programs favor leisure activities and reduce incentives to work. Regulatory and subsidy programs rearrange resource allocations of the private sector and may lead to less productive uses of our scarce resources. For all of these reasons, as well as many others, it is argued that the larger the share of the public sector in the economy, ceteris paribus, the slower the rate of potential economic growth.

Of course, many argue that government expenditures facilitate or improve the 'workings' of the private sector. This argument for non-market 
resource allocation may assume that the existence of some level of government sector is a prerequisite for a stable private sector or for a productive and growing economy. Certain resource reallocations may serve to lower frictions and inefficiencies that would be present in a purely market economy. The enforcement of property rights and individuals' rights to work or trade are fundamental ways in which the government is argued to facilitate the private market process. Cases of 'market failure,' provision of public goods and income redistribution are also areas where some argue the government should exert a role in resource allocation.

While arguments of facilitation of the private sector may suggest areas of 'appropriate' government expenditure, few would suggest that the level of that expenditure is boundless. Rather, 'government failure' may be associated with growth of the public sector. For example, the incentive structuring of 'appropriate' programs may discourage productive activity and higher productivity. When the allocation of more and more resources into the public sector is the usual 'solution' to unsuccessful but 'needed' programs, rather than a basic restructuring of them, a growing public sector could be associated with lower economic growth. 'Government failure' may also exist when resources are allocated to 'inappropriate' programs - those not justified by the goal of facilitating the private sector. ${ }^{1}$

To assume that recent growth in public sectors is solely fulfilling the facilitating role is difficult. As seen in Table 1, it is highly unlikely that economies with government expenditure to GDP ratios in the range of .23 to .57 are economies where public sector growth is for the sole purpose of 'supporting' the private sector. The rise in the average of that ratio from .32 to .40 may be interpreted as the measure of the growing rate of the government's absorption of new output in the economy. Clearly, as shown in Table 1 , much of the rise in expenditures is for 'social' expenditures. Moreover, if empirical evidence does suggest that government growth is inversely related to economic growth, then the argument that recent public sector growth facilitates the private sector becomes somewhat superficial.

\section{Previous literature}

The study of government growth has followed three distinct lines of inquiry. First, there exists empirical descriptions of the extent of public sector growth; for example, see Borcherding (1977) and Nutter (1978). The fact that different countries adopt different definitions, fiscal years and divisions of government makes for a rather formidable task of data collection. Consequently, empirical analysis of cross - national data has usually been of a fairly casual nature.

Second, there exists a rapidly growing literature on the root causes of 
public sector growth. ${ }^{2}$ Theories suggesting budget-maximizing bureaucrats, voter myopia, majority voting rules, economic growth, growth of special interests and many other reasons have been offered as underlying causes of government growth. One of the more commonly studied relations is that of Wagner's Law, or that economic growth is positively related to public sector size; see, for example, Gupta (1967), Bird (1971), Cameron (1978) and Meltzer and Richard (1983).

Third, there exists a few studies that attempt to measure the macro-effects of public sector size and growth. These studies hypothesize that public sector growth is inversely related to over-all economic growth. Landau (1983) finds a negative relation between the share of government consumption in GDP and the rate of growth of per capita GDP. Landau (1983) argues that total government expenditure would be preferable to an examination of government consumption expenditure but that access was available only for the latter variable. Orzechowski (1984) finds an inverse relation between economic growth and the tax rates of various countries.

Weede (1984) uses rent-seeking theory to explain cross-national differences in economic growth among industrialized economies. The basic premise is that government growth reinforces growth of the rent-seeking society and, consequently, contributes to adverse effects on overall economic performance. In general, Weede (1984) provides some empirical support for the hypothesis that tax revenue growth retards economic growth. ${ }^{3}$

OECD (1985) discusses the growth and determinants of social expenditures of countries belonging to the Organization for Economic Cooperation and Development. For example, OECD (1985) states ... 'Rather than being widely regarded as a major contributor to economic growth and macroeconomic stability, the view that the growth and financing of the public sector has, on balance, stifled growth now attracts widespread support (p. 14).' The main conclusion of OECD (1985) is ... 'through the end of the 1980s, there will be little or no room for increasing the scope of the welfare state'. The principal reason for this prescription appears to lie in its analytical rather than empirical base. On the empirical side, the same study finds: 'At the macroeconomic level, preliminary cross-country comparisons undertaken by the Secretariat have failed to reveal an inverse relationship between public sector size and economic performance as reflected in GDP growth rates, unemployment levels and inflation rates, or between public sector growth and inflation rates' (p. 15).

\section{Model}

Three models are used to measure the macro-effects of public sector size on 
economic growth. Cross-national linear regressions test the hypothesis that differences in public sector size and growth among countries are significant determinants of differences in economic growth among countries. Due to various omissions in the data, sample sizes range from 16 to 19 countries.

The following relations are examined.

$$
\begin{aligned}
& \text { RGDP }=a_{0}+a_{1} G E+c \\
& \operatorname{RGDP}=b_{0}+b_{1} R G E+u \\
& \operatorname{RGDP}=c_{0}+c_{1} G E+c_{2} R G E+d
\end{aligned}
$$

where RGDP = compound annual rate of growth of real GDP for selected years
$\mathrm{GE}=$ ratio of total government expenditure to GDP in initial period of RGDP measurement
$\mathrm{RGE}=$ compound annual rate of growth in GE for same selected years associated with RGDP
$\mathrm{e}, \mathrm{u}, \mathrm{d}=$ random disturbance terms.

Data on total government expenditure and GDP for the period 1960-1980 are obtained from OECD (1985). Total government expenditures are aggregated from central, state/provincial, local governments and social security funds and include both current and capital outlays. ${ }^{4}$ All three models are estimated for the time periods: $1960-1970,1970-1980$ and 1960-1980. While choice of these two sub-periods is arbitrary it is assumed that they conveniently allow us more information on the relation than is possible when only the entire 1960-1980 period is examined.

Equation (1) tests the hypothesis that higher initial period levels of public sector size are negatively related to economic growth. For example, it is hypothesized that economic growth over 1960-1980 is inversely related to the 1960 ratio of public expenditures to GDP. Therefore, initial levels of public sector size are determinants of future economic growth. The hypothesis that the contemporaneous relation between public sector growth and economic growth is negative is tested in equation (2). A contemporaneous relation captures the effects of concurrent trends in public sector growth on economic growth. Equation (3) tests the hypothesis that both initial period levels of public sector size and contemporaneous growth in that level are negatively related to economic growth.

Social expenditure data are also used to measure public sector size and growth. Due to its importance to total public expenditure growth over this period, it is hypothesized that differences in social expenditure patterns 
among countries are significant determinants of differences in economic growth among countries. The basic relations in equations (1) - (3) are used to examine the hypothesis.

$$
\begin{aligned}
& \text { RGDP }=a_{0}+a_{1} S E+e \\
& \operatorname{RGDP}=b_{0}+b_{1} \text { RSE }+u \\
& \text { RGDP }=c_{0}+c_{1} S E+c_{2} \text { RSE }+d
\end{aligned}
$$

where SE = ratio of social expenditure to GDP in initial period of RGDP measurement

$$
\begin{aligned}
\text { RSE = } & \text { compound annual rate of growth in SE for same selected years } \\
& \text { associated with RGDP }
\end{aligned}
$$

Data on social expenditures are from OECD (1985) and consist of any direct public expenditures on education, health services, pensions, unemployment compensation, other income-maintenance programs and welfare services. ${ }^{5}$ The same time periods are chosen as in the estimation of equs. (1) - (3). Equation (4) hypothesizes that higher initial period levels of social expenditure levels are inversely related to economic growth. The contemporaneous relation between social expenditure growth and economic growth are tested in equation (5). Both initial period levels and its contemporaneous growth are hypothesized to be inversely related to economic growth in equation (6).

\section{Empirical results}

Table 2 shows that the public sector's share of GDP (GE) in 1960 exerted a negative effect on economic growth over the 1960-1970 period; effects that are significant at the 1 per cent level of confidence. Contemporaneous growth in the public sector's share of the economy (RGE) is not a statistically significant determinant of GDP growth when it is the only explanatory variable in the equation. However, when GE and RGE are included in the same equation, both variables are found to exert statistically significant and negative influences on economic growth. When social expenditures are substituted for total government expenditures, both the initial level of social expenditure's share of the economy and its contemporaneous rate of growth are found to exert statistically significant and negative influences on economic growth. 
Table 2. Government growth and economic growth - Dependent variable: GDP growth over 1960-1970

\begin{tabular}{|c|c|c|c|c|c|c|c|c|}
\hline Equ. & Constant & $\mathrm{GE}$ & RGE & $\mathrm{SE}$ & RSE & $\overline{\mathrm{R}}^{2}$ & $\mathrm{~F}$ & $\mathrm{n}$ \\
\hline (1) & $\begin{array}{l}13.77^{* * *} \\
(5.10)\end{array}$ & $\begin{array}{c}-26.91^{* * *} \\
(3.22)\end{array}$ & & & & .38 & $10.36^{* * *}$ & 16 \\
\hline (2) & $\begin{array}{l}5.40^{* * *} \\
(11.13)\end{array}$ & & $\begin{array}{l}-.42 \\
(1.28)\end{array}$ & & & .04 & 1.64 & 16 \\
\hline (3) & $\begin{array}{l}13.86^{* * * *} \\
(5.40)\end{array}$ & $\begin{array}{c}-26.50^{* * *} \\
(3.33)\end{array}$ & $\begin{array}{l}-.39 * \\
(1.57)\end{array}$ & & & .44 & $6.96^{* * *}$ & 16 \\
\hline (4) & $\begin{array}{l}7.32^{* * *} \\
(4.25)\end{array}$ & & & $\begin{array}{c}-15.98^{*} \\
(1.33)\end{array}$ & & .05 & 1.80 & 17 \\
\hline (5) & $\begin{array}{l}6.02^{* * * *} \\
(8.98)\end{array}$ & & & & $\begin{array}{l}-.35^{*} \\
(1.75)\end{array}$ & .11 & $3.07 *$ & 17 \\
\hline (6) & $\begin{array}{l}8.40 * * * \\
(4.96)\end{array}$ & & & $\begin{array}{c}-16.73^{*} \\
(1.52)\end{array}$ & $\begin{array}{l}-.37 * * \\
(1.88)\end{array}$ & .18 & $2.81^{*}$ & 17 \\
\hline
\end{tabular}

* significant at $10 \%$ level.

** significant at $5 \%$ level.

*** significant at $1 \%$ level.

$\mathrm{n}=$ sample size.

t-statistics below estimated coefficients. 
Table 3. Government growth and economic growth - Dependent variable: GDP growth $1970-1980$

\begin{tabular}{|c|c|c|c|c|c|c|c|c|}
\hline Equ. & Constant & $\mathrm{GE}$ & RGE & $\mathrm{SE}$ & RSE & $\bar{R}^{2}$ & $\mathrm{~F}$ & $\mathrm{n}$ \\
\hline (1) & $\begin{array}{l}3.59^{* * *} \\
(2.84)\end{array}$ & $\begin{array}{r}-1.07 \\
(.29)\end{array}$ & & & & 0.0 & .09 & 19 \\
\hline (2) & $\begin{array}{l}4.01^{* * *} \\
7.91\end{array}$ & & $\begin{array}{l}-.42^{*} \\
(1.36)\end{array}$ & & & .05 & 1.82 & 17 \\
\hline (3) & $\begin{array}{l}5.24^{* * *} \\
4.07\end{array}$ & $\begin{array}{c}-3.84 \\
(1.04)\end{array}$ & $\begin{array}{l}-.36 \\
(1.14)\end{array}$ & & & .05 & 1.46 & 17 \\
\hline (4) & $\begin{array}{l}3.89 * * * \\
(4.38)\end{array}$ & & & $\begin{array}{l}3.62 \\
(.80)\end{array}$ & & 0.0 & .65 & 18 \\
\hline (5) & $\begin{array}{l}3.82^{* * *} \\
(5.32)\end{array}$ & & & & $\begin{array}{c}-.17 \\
(.66)\end{array}$ & 0.0 & .44 & 16 \\
\hline (6) & $\begin{array}{l}5.98^{* * *} \\
(4.40)\end{array}$ & & & $\begin{array}{c}-8.51^{* *} \\
(1.82)\end{array}$ & $\begin{array}{l}-.39^{*} \\
(1.82)\end{array}$ & .11 & 1.91 & 16 \\
\hline
\end{tabular}

* significant at $10 \%$ level.

** significant at $5 \%$ level.

*** significant at $1 \%$ level.

$\mathrm{n}=$ sample size.

$\mathbf{t}$-statistics below estimated coefficients. 
Table 4. Government growth and economic growth - Dependent variable: GDP growth 1960-1980

\begin{tabular}{|c|c|c|c|c|c|c|c|c|}
\hline Equ. & Constant & GE & RGE & $\mathrm{SE}$ & RSE & $\mathrm{R}_{2}$ & $F$ & $n$ \\
\hline (1) & $\begin{array}{l}10.45^{* * *} \\
(5.72)\end{array}$ & $\begin{array}{c}-19.34^{* * *} \\
(3.42)\end{array}$ & & & & .42 & $11.68^{* * *}$ & 16 \\
\hline (2) & $\begin{array}{l}4.65^{* * *} \\
(9.01)\end{array}$ & & $\begin{array}{r}-.38 \\
(.96)\end{array}$ & & & .00 & .92 & 16 \\
\hline (3) & $\begin{array}{l}10.57^{* * * *} \\
(5.74)\end{array}$ & $\begin{array}{c}-18.82^{* * * *} \\
(3.29)\end{array}$ & $\begin{array}{r}-.28 \\
(.92)\end{array}$ & & & .41 & $6.20^{* *}$ & 16 \\
\hline (4) & $\begin{array}{l}5.66^{* * * *} \\
(4.56)\end{array}$ & & & $\begin{array}{r}-10.65 \\
(1.24)\end{array}$ & & .03 & 1.54 & 17 \\
\hline (5) & $\begin{array}{l}5.22 * * * \\
(5.41)\end{array}$ & & & & $\begin{array}{l}-.39 \\
(1.08)\end{array}$ & .01 & 1.17 & 16 \\
\hline (6) & $\begin{array}{l}7.87^{* * *} \\
(5.06)\end{array}$ & & & $\begin{array}{c}-17.63^{* *} \\
(2.05)\end{array}$ & $\begin{array}{l}-.43 \\
(1.32)\end{array}$ & .19 & $2.82^{*}$ & 16 \\
\hline
\end{tabular}

* significant at $10 \%$ level.

** significant at $5 \%$ level.

*** significant at $1 \%$ level.

$\mathrm{n}=$ sample size.

t-statistics below estimated coefficients. 
Table 3 displays the results of the tests for the period 1970-1980. Only the coefficients of two equations are found to be statistically significant from zero; however, none of the equations explain a significant portion of the variability in economic growth when based on conventional F-statistic criteria.

The results displayed in Table 4 indicate that total government's expenditure as a share of the economy (GE) in 1960 explains a significant portion of variability in economic growth over 1960-1980. However, the contemporaneous growth rate of the public's share of the economy (RGE) is not a statistically significant determinant of economic growth. Only when included in the same equation with its rate of change (RSE) is the share of social expenditure in the economy (SE) a significant determinant of economic growth. In no case does the growth rate of the share of social expenditure in the economy exert an effect different from zero over the period $1960-1980$.

\section{Conclusion}

Analysis of government expenditure data of 19 industrialized countries over the period 1960-1980 supports the view that public sector size retards overall economic growth. The initial share of government in the economy is inversely related to future economic growth. While the contemporaneous growth rate of the public sector's share in the economy does not appear to matter as much as the initial level of that share, the tests do reveal that it exerts, at times, a negative and statistically significant effect on economic growth. The share of social expenditure, in the economy, as well as its growth rate, is also found to exert negative effects on economic growth.

The results of this study clearly call into question the wisdom of allowing public sectors to grow at the expense of private sectors. Moreover, two separate issues are involved. To private citizens, these results suggest that current public expenditure trends jeopardize their future wealth. To bureaucrats and politicians, these results suggest that future trends and appetites for non-market resource allocations will be constrained by the national income constraints that are inversely related to those same trends and appetites.

These tests are initial attempts to modeling the effects that shrinking private sectors exert on macroeconomic growth. Future studies may wish to consider fiscal policy measures such as tax policy. For example, supply-side economics argue that marginal tax rates play a significant role in economic incentives and, consequently, in determining macroeconomic growth. Given recent emphasis and popularity of this argument, it would be interesting to see whether or not differential marginal tax rates play a con- 
tributory role in determining differentials in growth rates among countries. In addition, Manage and Marlow (1985) argue that tax increases may promote increases in public expenditures and consequently, lead to lower future macroeconomic growth. Clearly, investigation of these issues will yield greater insight into the economic costs of public sector growth.

\section{NOTES}

1. Obviously, the line to be drawn between those functions which do and do not serve the facilitating role lies in the eye of the beholder. For example, some may argue that agricultural subsidies allow for greater resource allocation into crops that would be underprovided in the private sector; i.e., a purely private market would set a price higher than desired by such proponents. Even though the argument may weaken somewhat in the case of tobacco products, some would still argue that growth in these agricultural programs provides for an economy that is superior to a purely private one. Clearly, all government programs have similar proponents - otherwise those programs would not exist.

2. See Tullock (1959), Downs (1961), Niskanen (1971), Breton (1974), and Peltzman (1980).

3. Manage and Marlow (1986) argue that the proper way to measure the growth of government is not by the growth in tax revenue. Tax revenue is an incomplete measure of the level of resources absorbed by the government sector. At any level, government expenditure is always financed by some combination of debt-issue, direct taxation and indirect taxation through inflation. Tax revenue is only one part of the total funding level. Accordingly, aggregate expenditure provides a better measure of public sector growth.

4. Of course, this is only a partial measure since it excludes many of the effects of subsidies, tariffs and government regulations on the private economy. Our measure only represents direct public expenditure for those interventions into the economy.

5. It is noted that the social data for the entire economy are incomplete in those cases where some countries have private health care, private schools, private pensions, sick pay, disability insurance schemes, and charity. However, the available data are still a good proxy of government social expenditure.

\section{REFERENCES}

Bird, R.M. (1971). Wagner's law of expanding state activity. Public Finances 26: 1-26.

Borcherding, T.E., Ed. (1977). Budgets and bureaucrats. Durham: Duke University Press. Breton, A. (1974). The economic theory of representative government. Chicago: Aldine.

Cameron, D.R. (1978). The expansion of the public economy: A comparative analysis. American Political Science Review 72 (December): 1243-1261.

Downs, A. (1961): In defense of majority voting. Journal of Political Economy 69 (April): 192-199.

Gupta, S. (1967). Public expenditure and economic growth: A time-series analysis. Public Finance 4: 423-461.

Landau, D. (1983). Government expenditure and economic growth: A cross-country study. Southern Economic Journal 49 (January): 783-792.

Manage, N., and Marlow, M.L. (1986). The causal relation between federal expenditures and receipts. Southern Economic Journal 52 (January): 617-629.

Meltzer, A.H., and Richard, S.F. (1983). Tests of a rational theory of the size of government. Public Choice 41: 403-418. 
Niskanen, W.A. (1971). Bureaucracy and representative government. Chicago: AldineAtherton.

Nutter, G.W. (1978). Growth of government in the West. Washington, D.C.: American Enterprise Institute.

OECD (1985). Social expenditure 1960-1990: Problems of growth and control.

Orzechowski, W. (1984). International perspectives on tax policy and economic growth. Economic Outlook (October). Washington, D.C.: U.S. Chamber of Commerce.

Peltzman, S. (1980). The growth of government. Journal of Law and Economics 23 (October): 209-287.

Weede, E. (1984). Democracy, creeping socialism, and ideological socialism in rent-seeking societies. Public Choice 44: 349-365. 